\title{
Bill deMello
}

Anthony deMello: The Happy Wanderer. Maryknoll: Orbis Books, 2013.

Pp. 272. $\mathrm{Pb}, \$ 25$.

A few years before his untimely death in 1987, the renowned spiritual teacher and Indian Jesuit, Father Anthony de Mello, gave an eight-day retreat for fellow Jesuits. A fresh-faced youth at the time, I was delighted to have the opportunity to encounter this legendary spiritual master. "Tony" spoke to us for at least five hours each day. Although he did without a single note, he was never at a loss for words - and I cannot recall a single dull moment. Seemingly without effort, he held our attention, by turns fascinating, irritating, and uplifting us. But after a week of listening to this magnetic speaker, who so delighted in attacking sacred cows and undermining cherished convictions, it dawned on me that I was none the wiser as to who the real Anthony de Mello was. To adapt Winston Churchill's description of Russia, Tony was a riddle, wrapped in a mystery, inside an enigma.

This biography, written by his brother Bill, doesn't solve the riddle, but does partly unwrap the mystery, in giving us greater access than ever before to this enigmatic character. Ironically, when Bill first conceived the project of writing the life story of his older brother (whom he deeply idolized), he realized how little he knew about his beloved sibling. A full thirteen years older, Anthony left home to join the Society of Jesus before Bill had reached his fourth birthday. There were enormous gaps to be filled. But Bill's charm — and blood relationship to Anthony - coaxed valuable stories and reflections from dozens of people.

The result is an endearing and engaging portrait, which depicts not only Anthony's personal and spiritual development, but also Bill's growing understanding of his older brother. The accident of birth made Bill and Anthony brothers, but it was only through working at the relationship posthumously that Bill came to appreciate his brother as the gem he truly was.

The first part of the book traces Anthony's story from childhood until late in life, culminating with chapter eight, which narrates the July 1973 inauguration and subsequent evolution of the Sadhana Institute, the center for spirituality and human formation founded by de Mello. Anecdotes from de Mello's childhood and youth reveal a striking intelligence from early on, a sense of integrity, a winning charm, as well as a streak of stubbornness, allied to an unerring conviction he was destined to be a priest. These initial chapters are named after the principal steps of Jesuit formation: novitiate, philosophy, regency, and theology. They offer non-Jesuit readers a helpful context for Anthony's growth. There is also a slight tendency to romanticize both individual Jesuits and the Society of Jesus itself. There is no doubt that individual Jesuits of the time (de 
Mello entered the novitiate in July 1947) were benign and well-meaning, but the whole structure easily fostered affective underdevelopment and spiritual immaturity, the root of Anthony's later efforts helping priests and religious deal with unresolved psychological issues. At the beginning of his Jesuit formation, de Mello himself succumbed to the rigidity that often besets overzealous new converts. But Bill rightly identifies Anthony's two years studying philosophy in Barcelona as a decisive turning point. The change had little to do with philosophy, and more to do with Father José Calveras, an authority on the Spiritual Exercises and spiritual director of the house, whom de Mello credited with first teaching him to pray properly. On returning to India, Anthony's earlier rigidity had melted away, and his warm humanity had come to the fore.

After ordination, graduate studies, and initial short-term working assignments, Tony discovered his true niche in 1973, when he founded the Sadhana Institute, to which he was to devote the greatest part of his energy and creativity. "Sadhana was Tony and Tony was Sadhana" as one person expressed it (145). Tony was too dynamic to stay with a fixed formula, and his approach developed and changed as he gathered new insights. In the process, he changed the lives of the many people who entrusted themselves to his avant-garde cocktail of psychology and spirituality.

The second part of the book focuses on de Mello's ideas and worldviewneither one easy to pin down. Tony did not have a systematic bone in his body, and his thinking was so experimental and fluid that he was ready to renounce a previous belief at a moment's notice if he found a better alternative.

De Mello is sometimes called an 'Eastern' or 'Asian' Christian, and the claim has a large measure of truth: he borrowed liberally from Hinduism, Buddhism, Judaism - to mention only a few - to build his vast repertoire of stories and deep fund of spiritual wisdom. Furthermore, one of Anthony's major innovations in teaching was to introduce Vipassana meditation, an awareness of breathing and bodily sensations aimed at inducing calm and serenity (149). Moreover, in the final appendix to the book, Bill reproduces a stirring article Anthony wrote for the periodical Concilium, entitled "An Eastern Christian Speaks of Prayer."

At the same time, as Bill underlines, "not only was he a great Jesuit, he helped other Jesuits to become great Jesuits as well" (177). Anthony's essentially Jesuit approach is evident in how his spirituality constantly affirmed the world and his aim was always that of "helping souls." He was certain that education (especially through the Sadhana Institute) was a potent means of forming minds - and more particularly, hearts. He sought God in all things, opening up 'God-spaces' within people that they were unaware of, a gift elucidated in chapters eleven and twelve. His goal was to see people flourish both humanly 
and spiritually. Anthony managed to find grace at work everywhere, even in the most inconsequential aspects of a person's temperament. Moreover, he had that typically Jesuit flexibility which impelled him to adapt his techniques as needed.

The suppression of the Society of Jesus cut off a living link with the order's origins. But in his maverick manner, Anthony de Mello brought us back to the infectious vision of the early Society. This biography, published on the eve of the 2ooth anniversary of the restoration, presents a supremely talented yet utterly human man, who continues to inspire people in a manner of which Ignatius of Loyola and the first Jesuit companions would have been proud.

Thomas G. Casey, S.J.

St. Patrick's College, Maynooth

thomas.casey@spcm.ie

DOI $10.1163 / 22141332-00203005-25$ 